\title{
CO-OCCURRENCE OF RISK BEHAVIORS AMONG SPANISH ADOLESCENTS
}

\section{CONCURRENCIA DE COMPORTAMIENTOS DE RIESGO ENTRE ADOLESCENTES ESPAÑOLES}

Carmen Meneses cmeneses@chs.upcomillas.es

Comillas University ICAI-ICADE of Madrid. Spain

Antonıo RúA rvieites@cee.upcomillas.es

Comillas University ICAI-ICADE of Madrid. Spain

NuRIA Romo nromo@ugr.es

University of Granada. Spain

EugenIA GIL egil@us.es

University of Sevilla. Spain

JORGE UROZ juroz@chs.upcomillas.es

Comillas University ICAI-ICADE of Madrid. Spain

IÑAKI MARKEZ imarkez@euskalnet.net

Basque Health Service (Osakidetza). Bilbao. Spain

\begin{abstract}
This work examines the co-occurrence of risk behaviors among Spanish adolescents. The analyzed behaviors were sexual activity, the use of alcohol and other drugs, violent conduct and behaviors related to driving mopeds or scooters. The sample consisted of 4,091 adolescents between the ages of 13 to 18, all of them enrolled in one of the four compulsory years of secondary education, the approximate equivalents of the 7th to 10th grades in the US educational system. Cluster analysis indicates that there are four risk profiles, one of which is the profile with the greatest risk and the highest co-occurrence of risk behaviors. This group represents $13 \%$ of the sample and is noteworthy for using illegal drugs, driving under the influence of drugs and other activities carried out under the influence of alcohol. Differences have been found among the various profiles according to sociodemographic characteristics such as sex, grade, perception of the family's economic situation and ethnicity. The findings are discussed and some suggestions are given for prevention intervention.
\end{abstract}

\section{KEYWORDS}

Adolescents; Risk behaviors; Risk profiles; Spain. 


\begin{abstract}
RESUMEN
Este trabajo examina la concurrencia de comportamientos de riesgo en adolescentes españoles. Los comportamientos analizados fueron la actividad sexual, el consumo de alcohol y otras drogas, conductas violentas y comportamientos en la conducción de ciclomotores o motocicletas. La muestra incluye 4.091 adolescentes de 13 a 18 años, perteneciente a educación secundaria obligatoria. Los resultados obtenidos muestran cuatro perfiles de riesgo, siendo uno de ellos el perfil de más alto riesgo y concurrencia de comportamientos arriesgados. Este grupo supone el $13 \%$ en el que destacan las conductas de consumo de drogas lícitas, conducir bajo los efectos de droga y otras conductas realizadas bajo los efectos del alcohol. Se encuentran diferencias entre estos perfiles y las características sociodemográficas como el sexo, el curso, la percepción sobre la economía familiar y la etnicidad. Se discuten los resultados obtenidos y se ofrece algunas sugerencias para la prevención.
\end{abstract}

\title{
Palabras Claves
}

Adolescentes; Comportamientos de riesgo; Perfiles de riesgo; España.

\section{INTRODUCTION}

Risk behaviors and situations of risk during adolescence are of great concern to parents, teachers and health professionals due to the negative consequences they may have in later development (Lightfoot 1997; Fischhoff et al. 2001; Flay 2003). The use of alcohol and drugs, early and unprotected sexual relations, reckless behavior while driving scooters and other vehicles, inappropriate diet, a sedentary lifestyle, school failure or dropout, violence and anti-social conduct are the main risk behaviors that have been studied in relation to adolescent mortality and morbidity in industrialized societies (Dolcini et al. 1989; Arnett 1992; Graham 2004).

Following the example of Coleman and Hagell (2007), when the concept of risk is applied to adolescents, authors often distinguish between risk factors, risk behaviors, adolescents at risk and adolescents who pose a risk to society because of their conduct. There is extensive international literature on each of these dimensions of risk and on many occasions it is applied indiscriminately to all adolescents, without taking into account the differences that exist among them (Ingersoll and Orr 1989). It may be true that the processes of globalization are coupled with a certain globalization of risk behaviors in that many of the elements of culture used by teens are disseminated by the mass media, which can

"The authors of this study wish to thank the schools in Andalusia, Madrid and the Basque Country that have collaborated in the collection of data. Without their assistance this project would not have been possible. We would also like to thank the Ministries of Education of Andalusia and of the Basque Country for supporting this research. This study is part of the National R+D+I Project, "Adolescence and Risk: A comparative study in three Autonomous Communities" subsidized by the Spanish Ministry of Science and Innovation, Reference: SEJ2005-03839, and Risk, Adolescence and Ethnicity: Comparing three geographical areas in Spain, Reference: CSO2009-07732; the general objective of which is to study the risk behaviors of adolescents. The authors thank Alexia Weninger for the translation and suggestions. 
prompt young people to follow similar trends in various aspects of their lives (clothes, food, music, films, leisure activities, etc.) in very different places. However, while many trends do in fact cross borders, conduct by adolescents is also influenced by the socialization contexts that are near them, where social and cultural aspects can shape, reduce or eliminate behaviors (Essau 2004). As set forth by Arnett and Arnett (1994), differences in the socialization of adolescents can have an effect on the presence and frequency of risk behaviors. In their comparison of the risk behaviors among Danish adolescents and adolescents in the United States, these authors pointed out that the influence of legal norms, educational practices and social customs can mark different levels of risk in the conduct displayed by adolescents of any given country, society or culture.

A relevant question that has been posed with regard to risk behaviors is whether such behaviors are perhaps something that is normative and necessary for the growth, maturation and configuration of the identity of young people (Ingersoll and Orr 1989; Lightfoot 1997; Essau 2004) or if on the contrary these behaviors are a problem in terms of health and development in the transition to adulthood (Spear 2001; Carrasco 2002). It has been suggested that certain conduct is more prevalent during adolescence than in other periods (Arnett 1992; Guilamo-Ramos et al. 2005) and adolescents have been characterized as risk-takers who feel invulnerable to the harm or dangers to which their actions might lead (Dolcini et al. 1989; Jessor 1991). However, it is not clear that adolescence is the period of greatest risk since it has also been pointed out that many of the behaviors studied in adolescents are more prevalent among adults, and that their presence increases with age (Ingersoll and Orr 1989; Brener and Collins 1998). In addition, adolescence has been treated as a very long period. An earlier phase from ages 12 to 16, and another, later phase from 16 onwards have been distinguished, and risk behaviors may vary in prevalence, frequency and intensity during the two phases (Brener and Collins 1998).

In Spain, numerous studies have been conducted on drug use among adolescents. Every two years the Spanish Ministry of Health performs a survey of the school-age population to determine how widespread drug use is. The most recent survey, conducted as part of the National Plan on Drugs (NPD) in 2007, indicated that $53.2 \%$ of students between the ages of 14 and 18 had gotten drunk at least once and that $25.7 \%$ had done so in the last month. The drugs most commonly used by Spanish adolescents in the last year were alcohol $(74.9 \%)$, tobacco (34\%) and cannabis (29.8\%). Also, one out of every four adolescents had consumed alcohol before becoming involved in a fight. Such systematic data is not available for other risk behaviors. However, in the area of violencerelated conduct, some works have pointed out that between $1 \%$ and $7.6 \%$ of the adolescents in secondary education acknowledge that they regularly show aggressive behavior (Spanish Ombudsman 2007; Oñederra et al. 2005). With regard to conduct in the area of sexual activity, $47.8 \%$ of boys between the ages of 15 and 19 have had complete sexual relations, while the figure is $40.4 \%$ in the case of girls. In both cases, the lower the age, the smaller the percentage (INJUVE 2004). Another study (Hidalgo et al. 2000) found that around $20 \%$ of adolescents in Madrid use no contraception in their sexual relations 
( $21.6 \%$ boys and $15.6 \%$ girls). Finally, in terms of conduct in the area of road safety, in the year 2006 the number of young people involved in traffic accidents as drivers of scooters or motorcycles, either on the motorway or in urban areas, was 4,538. Of these, approximately $85 \%$ were male, according to Spain's National Traffic Administration (DGT 2007). All of this data must be placed within a social, political and economic context which is very different from that of other countries. In Spain it is not legal to drive a vehicle until the age of 18 . Before that age adolescents can only drive mopeds and scooters ${ }^{1}$ with parental authorization. Sexual relations, unintended pregnancies and abortion rates have increased in recent decades among adolescents and youth in Spain (Women's Institute, Ministry of Equality 2008). The democratization of Spain, a process that began with the death of Franco in 1975, has brought about greater equality between the sexes and the possibility of engaging in behavior that previously was not socially permitted, particularly for women. Especially relevant here is the relationship between young Spaniards and the use of alcohol and other drugs. In Spain the drinking age was not raised to 18 until the arrival of the new millennium, and there are still some regions of the country in which the minimum drinking age is only 16 (such as Asturias in Northern Spain). Therefore, until just a few years ago the use of alcohol and tobacco by minors was not considered a serious problem. This situation can be attributed in part to the heroin crisis that affected Spain (Gamella 1997), which had the effect of obscuring the consumption of more mainstream drugs. Alcohol and tobacco use thus received little attention in terms of prevention efforts. Frequently, legal modifications arise as a consequence of certain behaviors that are taking place in society and legislation generally lags a few steps behind. The behavior of Spanish adolescents is partly the result of socialization and the changes that have occurred in Spain over the last three decades; an intense period in Spain's history that young people's parents experienced firsthand. As some studies suggest (Gittelsohn et al. 2001; Garcia and Gracia 2009), the messages sent by parents and the approval or rejection that parents display with regard to these behaviors play an important role in maintaining their prevalence among adolescents.

Jessor's Problem Behavior Theory (Jessor 1991) posits that risk-taking behaviors tend to co-occur or correlate (Brener and Collins 1998; Zweig et al. 2001; Essa, 2004; Rodriguez et al. 2008) in adolescents in such a way that when one risky conduct arises, others may appear as well, producing what is known as the Risk Behavior Syndrome. What is the reason for this interrelation or concurrence among risk behaviors in adolescence? Various ideas have been put forward in an attempt to answer this question. First, it has been suggested that risk behaviors occur in progression. In other words,

\footnotetext{
${ }^{1}$ The minimum age for driving a moped is 14 and parental authorization is required. To obtain a license to drive a moped (less than $50 \mathrm{cc}$ ), young people must pass some tests and a driving exam. From the ages of 14 to 16 , young people can drive a scooter (from 50cc to $125 \mathrm{cc}$ ) with a Type A1 license after passing an exam and psychotechnical tests. To obtain a Type A license for more powerful motorcycles, drivers must be 18 years old and have two years of experience with an A1 license.
} 
certain types of conduct precede others, such as the use of legal drugs preceding the use of illegal drugs, or drug use preceding sexual activity (Kandel and Yamaguchi 1993; Dorius et al. 1993; Essau 2004). A second suggestion is that the causes or factors of risk may be the same for all the conduct we consider risky (Cooper et al. 2000; Flisher et al. 2000; Eklund and Klinteberg 2005; Anderson et al. 2007) because all risk behaviors may have the same function in adolescents, that is, contributing to the transition towards adulthood (Jessor 1991). In this sense, experimentation as a step in the acquisition of experience, or in the construction of identity, would be one of the purposes of many of the risk behaviors of adolescents (Dworkin 2005). A third approach would be to speak of certain profiles or groups of adolescents which could be described as risk profiles due to the persistence and intensity of their behavior. Here Graham (2004) distinguishes among three groups of adolescents depending on the risk behaviors they display: the first group, considered non-problematic and conformist, would be the largest group; a second group, non-problematic and non-conformist, would be a minority; and a third group, described as problematic, would also be a minority. The latter is the group that requires special attention and it is calculated to be one out of every five adolescents. However, the author states that it is difficult to estimate the size of the first two groups, since the situation is not static; adolescents in this phase may move back and forth between groups. In other works (Basen-Engquist et al. 1996 in Zweig et al. 2001) authors distinguish between two groups of adolescents according to their risk behaviors: a first group that engages in risk behavior considered normal during adolescence (use of drugs, engaging in unprotected sex, not using seatbelts, actions carried out while under the influence of alcohol or drugs, etc.) and another group with risk behaviors considered to be more destructive (use of intravenous drugs, use of cocaine or crack, suicidal behavior, etc.).

Another consideration that has been discussed in the literature is that the perception and management of risk may vary by gender (Dolcini et al. 1989; Byrnes et al. 1999; Romo 2001). Males show a lower perception of risk and greater involvement in risk behaviors (Ingersoll and Orr 1989; Brener and Collins 1998). One explanation for these differences has been the experience of socialization in gender roles that differ for men and women. It may be that the male image is associated with risk to a greater extent than the female image. However, it has been pointed out that there is little or no gender difference in certain risk behaviors, and that this may be an indication that the transition of gender roles for the younger generations is coming to an end (Gibbons et al. 1989). In addition to gender, ethnicity has been studied in relation to risk behaviors among adolescents (Weden et al. 2005). In some works, the ethnic identity of certain minority groups has been shown to be a factor that protects against certain health risk behaviors (Marsiglia et al. 2008), while in other works this does not seem to be the case (Brindis 1995). For both ethnicity and gender, whether or not these variables are protection factors or risk factors depends on the social norms, values and expectations associated with each ethnic group and with each gender in a given society (Kobayashi et al. 2008). 
The situation in Spain differs from the North American context and also from that of other European countries. It is important to point out that within the last decade Spain began to receive a high number of immigrants from places such as Morocco, Latin America, Sub-Saharan Africa and Eastern Europe, and is therefore becoming a multicultural society. According to recent data from the Spanish Institute of Statistics (INE), as of 1 January 2008 there were $5,220,577$ resident foreigners in Spain (15.5\% of the country's population) and of that figure, $10.1 \%$ were adolescents between the ages of 10 and 19 (NSI 2008). However, even prior to the migratory waves, Spanish society was not homogenous. The white population of Spain has traditionally co-existed with gypsies; an ethnic group that has been present in Spain for over 500 years (Gamella 2004). It is estimated that the gypsy population in Spain is approximately 600,000 (Martín and Gamella 2005) and that about $25 \%$ of it is between the ages of 10 and 19 (Alfageme and Martínez, 2004). Although numerous studies have been performed on this ethnic minority in Spain, few of them have addressed the risk behaviors of adolescents, and such conduct has been assumed to be similar to that of the rest of Spanish adolescents. The main studies on gypsy adolescents have focused on school integration problems and their living conditions, perhaps because such topics were considered a higher priority (Alfageme and Martínez 2004). In addition, since Spain has seen such an increase in its immigrant population, most research has examined the integration processes experienced by the foreign population and few studies have studied health risk behaviors. Similarly, studies performed in Spain have paid little attention to the ethnicity variable.

The perception and assessment of the risk involved in adolescent behavior can vary according to the sociocultural context and the characteristics of the communities involved (Arnett and Jensen 1994). It has been suggested that it is easier for researchers to classify children and adolescents in risk groups than to classify the contexts that bring about these situations (Kagan 1991). Adolescents may perceive some of the behaviors to be less risky than adults do (Millstein and Halpern-Felsher 2001) and to assess some of them as beneficial or desirable (Maggs et al. 1995; Lightfoot 1997; Hazard 1999). This has led to a great interest in studying the contexts in which such behaviors take place and the meanings associated with them for the people involved (Rhodes 1997; Hart 1999; Hazard 1999). In Spain, the patterns of co-occurrence of risk behaviors among adolescents have received little attention and that is why it is one of the objectives of this study. The questions we address are the following: To what extent can the co-occurrence patterns described in the international literature be applied to Spanish adolescents? Are the patterns of co-occurrence of risk behavior valid for the majority of Spanish adolescents?

The aim of this work is to describe the co-occurrence patterns of risk behaviors in Spanish adolescents and to determine whether such co-occurrence patterns differ by sociodemographic characteristics such as sex, age, grade, economic situation and ethnicity. 


\section{METHOD}

\section{Data and Sample}

The data was obtained through self-administered questionnaires that were completed in the classroom by a sample of students in the four years of compulsory secondary education in three different regions of Spain: the Basque Country, in the northern part of Spain; Madrid, in the middle of the country and Andalusia, in southern Spain. The samples from Andalusia $(n=1,907)$ and Madrid $(n=1,720)$ were representative of the population of students in compulsory secondary education? ${ }^{2}$.

The sampling procedure used was multistage random sampling, with a sampling error of 2.5, population variance of $50 \%$ and a confidence level of $95 \%$, with a minimum of 1,600 questionnaires corresponding to each region studied. The schools were sampled using proportional allocation (among public, private and semi-private schools). The classrooms of each grade of compulsory education were then selected randomly at the schools included in the sample, with 25 students being estimated for each classroom. Average completion time was 40 minutes and the questionnaires were administered in April and May of 2007. As usual, students were guaranteed that their responses would remain anonymous and participation was voluntary. The final sample consisted of 4,091 students in compulsory secondary education from 60 classrooms in 17 schools in Madrid, 83 classrooms in 23 schools in Andalusia and 20 classrooms in 6 schools in the Basque Country.

Of the schools, $41.5 \%$ were public and the rest were private or semi-private. $25.3 \%$ percent of the students were in the first year of compulsory secondary education (equivalent to 7 th grade in the US system), $24.5 \%$ were in the second year (8th grade), $26.3 \%$ were in the third year (9th grade) and $23.7 \%$ were in the fourth year (10th grade).

To measure ethnicity, we used the ethnic group option chosen by each student. Although they could choose from a variety of options, we placed all those who considered themselves "White" in one group and those who selected other ethnic groups (Black, Gypsy, North African, Asian, Latin, Indian, etc.) in the "Other" group33.

\footnotetext{
${ }^{2}$ It was determined that the three samples would be studied in the same period - the months of April and May of 2007 -but sampling could be completed within this time frame only in the two autonomous communities mentioned. It would have been possible to continue in the Basque Country in September but we decided against it because that was a different academic year and we thought it might constitute a bias. The reason that sampling could not be completed in the Basque Country was that other national and regional surveys were being conducted that same year, which made the schools less inclined to agree to participate in our study. In addition, the researchers in Madrid and Andalusia were involved in the collection of questionnaires at the schools, while this circumstance was not possible in the Basque Country.

${ }^{3}$ The ethnicity results obtained were grouped into two options due to the dispersion of responses and the small size of the resulting groups because when it came time to apply the different analyses and statistical tests the samples were too small.
} 
As for the economic variable, we used the students' perception of their family's economic situation. Respondents indicated whether they perceived the household's economic situation to be good or bad (the latter comprised two categories: problems making ends meet and serious economic difficulties, which were then unified in a single category). We did not ask them about their parents' income because we considered it likely that many of them would not know the answer. For this reason we chose to ask about their perception and used that variable to get an idea about the family's economic situation.

\section{Measures of Risk}

Nine indicators were used to measure the risk exposure of young people between the ages of 13 and 18 . These nine indicators fall within five types of risky conduct: sexual behavior, use of alcohol and drugs, behavior on the road, violent behavior, and actions carried out under the influence of alcohol and drugs. All the indicators were constructed from the different variables contained in the questionnaire completed by the adolescents using various analytical procedures. All measures are ordinal and have values between 0 and 5 such that the higher the score, the greater the risk or risk exposure.

SEXUAL BEHAVIOR - This was constructed with one indicator only.

Indicator 1: Sexual activity. Two variables were used to construct this indicator of risk level in terms of the adolescents' activity: one variable that asked directly if the young person had had intercourse with penetration and a second variable asking how often in the last 12 months he or she had used protection during sexual relations, with discrete values of 1 to 5 corresponding to always, almost always, sometimes, hardly ever and never. It is therefore an ordinal indicator that measures risk level with values ranging between 0 and 5 indicating no risk to extreme risk.

USE OF ALCOHOL AND DRUGS - The students were asked three types of questions: their use of different drugs over the last year; how often they use the drugs, and their perception of the accessibility to each of them.

In order to create an indicator measuring the risk level among adolescents in terms of drug and alcohol use, a factor analysis was performed on the variables pertaining to the frequency with which these substances (tobacco, beer, wine, mixed drinks, cider, coffee, hash, ecstasy, inhalants, amphetamines, tranquilizers, LSD, cocaine and heroin) had been consumed over the last 12 months (never, a few times a year, 2 or 3 times a month, 2 or 3 times a week, regularly but only on weekends, every day).

The KMO test of sampling adequacy (0.886), Bartlett's test of sphericity ( $\mathrm{p}=000)$, and the determinant of the correlation matrix all indicated that performing a factor analysis was appropriate. Principal component extraction and Varimax rotation were used, which made it possible to obtain a more precise interpretation of the factors and a more 
balanced weighting of the factors. Following the retention criterion according to which the eigenvalue associated with the factor must have a value greater than 1.0, two factors accounting for $55.8 \%$ of the variance were retained. It was found that 14 variables could be synthesized into two factors, from which the following two indicators were defined:

Indicator 2: Use of Illegal Drugs. The first factor, which we have called "lllegal Drugs", reflects the use of substances such as LSD, ecstasy, amphetamines, cocaine, inhalants, tranquilizers and heroin. The scores are defined as follows: 0 if the person has never used LSD, amphetamines, ecstasy, cocaine, inhalants, or heroin; 1 if he or she has used one or two of the substances a few times in the past year; 2 if he or she has used one or more of the substances 2 or 3 times a month; 3 if he or she has used one or more of the substances 2 or 3 times a week; 4 if he or she has used them regularly but on weekends only; and 5 if he or she has used them on a daily basis.

Indicator 3: Use of Legal Drugs. This indicator, which is the second factor of the analysis, was called "Legal Drugs" and reflects the use of substances which are more easily obtained by adolescents such as wine, mixed drinks, beer, tobacco, hashish, cider or coffee. In Spain, hashish is not legal, but it is the illegal psychoactive substance that is most tolerated, used and accessible by the Spanish population, especially young people. The tolerance and normalization of the use of this substance has resulted in it being perceived very differently from other illegal substances in terms of risk and danger. For this reason, it has been grouped with this factor. The scores are as follows: 0 if the young person has never consumed any of the following substances: beer, wine, mixed drinks, hard cider, tobacco, hashish or marijuana, or coffee; 1 if he or she has used one or two of the substances a few times in the past year; 2 if he or she has used one or more of the substances 2 or 3 times a month; 3 if he or she has used one or more of the substances 2 or 3 times on weekdays; 4 if he or she has used them regularly but on weekends only; and 5 if he or she has used them on a daily basis.

VIOLENT BEHAVIOR - An indicator was constructed using two variables.

Indicator 4: Violence. Based upon the variables that reflect whether the young people have been involved in a fight in the last 12 months and, if so, the number of times, the variable Risk of Physical Fight is defined as follows: 0 if he or she has never fought; 1 if he or she has fought once over the last 12 months; 2 if he or she has fought 2 or 3 times over the last 12 months; 3 if he or she has fought 4 or 5 times over the last 12 months; 4 if he or she has fought 6 or 8 times over the last 12 months; and 5 if he or she has fought more than 8 times over the last 12 months.

ROAD SAFETY - Respondents were asked how often over the last 12 months they had been involved in certain driving-related circumstances (never, occasionally, quite a few times, many times). Again, in order to obtain a clearer image of the relations of interdependence among 
all the variables considered in this sphere, a factor analysis was conducted. The KMO test of sampling adequacy (0.830), Bartlett's test of sphericity $(p=000)$, and the determinant of the correlation matrix all indicated that performing a factor analysis was appropriate. Principal component extraction and Varimax rotation were used, which made it possible to obtain a more precise interpretation of the factors and a more balanced weighting of the factors. Following the retention criterion according to which the eigenvalue associated with the factor must have a value greater than 1.0 , three factors accounting for $55 \%$ of the variance were retained. These factors were the basis for the construction of the following three indicators: Indicator 5: Riding/Driving on Drugs. This refers to the adolescent driving on drugs or riding with an intoxicated driver. This factor encompasses the behavior as a whole given by the following variables: "I've been a passenger on a scooter when the driver had used an illegal drug"; "I've been a passenger in a car when the driver had used an illegal drug"; "I've been a passenger on a scooter when the driver had consumed alcohol"; "I've driven a scooter after consuming alcohol"; and "I've been a passenger in a car when the driver had consumed alcohol". That is, all of the variables that are related to driving under the influence of drugs or alcohol. All the factor loadings are positive such that high scores for this factor indicate a high risk and vice versa. First of all, the sum variable is calculated based upon all the variables included in the Driving under the influence of drugs and alcohol factor: 0 if it equals $5 ; 1$ if it is between 6 and $7 ; 2$ if it is between 8 and 10; 3 if it is between 11 and 13; 4 if it is between 14 and 17; and 5 if it is between 18 and 20 .

Indicator 6: Recklessness on the road. This corresponds to the second factor of the analysis and the variables encompassed by it are the following: "I enjoy going really fast", "I like taking risks", "I have been in a car going over the speed limit", "I have walked across the street where doing so is not allowed", "I've been a passenger on a scooter going over the speed limit and we challenge each other on the road". That is, all the variables that reflect reckless behavior on the part of the young person. All the factor loadings are positive. The sum variable is calculated based upon the variables included in the Recklessness factor, which takes the following values: 0 if it is between 6 and $8 ; 1$ if it is between 9 and $11 ; 2$ if it is between 12 and $14 ; 3$ if it is between 15 and $17 ; 4$ if it is between 18 and 20; and 5 if it is between 21 and 24 .

Indicator 7: Lack of road safety. This is the third factor and it encompasses the following variables: "I put my seatbelt on when riding in a car with a friend", "I put my seatbelt on when riding in a car with my mother/father", "I wear a helmet when on the scooter". In other words, these are variables that measure to what extent the respondent engages in road safety practices such as wearing helmets while on a scooter or using seatbelts in a car. The factor loadings are positive, such that the higher the score for this factor, the more frequent the bad practice and vice-versa. The sum variable associated with the three variables encompassed in the Lack of road safety factor is calculated as follows: 0 if it equals $3 ; 1$ if it is between 5 and $6 ; 2$ if it is between 7 and $8 ; 3$ if it is between 9 and $10 ; 4$ if it is 11 ; and 5 if it is 12 . 
BEHAVIOR UNDER THE EFFECT OF DRUGS. The adolescents were asked about different situations that they may have experienced under the influence of alcohol and other drugs over the last 12 months. In order to analyze the interdependence and relationships between the total set of variables analyzed, a factor analysis was conducted in an attempt to find dimensions underlying the data as a whole that would serve as a guide in drawing up an indicator of risk exposure. The KMO test of sampling adequacy (0.838), Bartlett's test of sphericity $(p=000)$, and the determinant of the correlation matrix indicated that performing a Factor Analysis was appropriate. Principal component extraction and Varimax rotation were used. Two factors accounting for $43 \%$ of the variance were retained, which is less than in previous models although the main function here is simply to detect the underlying structure so that the indicators can then be constructed. The two factors were used to construct two indicators.

Indicator 8: Behavior under the influence of alcohol. Actions performed under the infuence of alcohol: getting drunk; meeting and drinking with large groups of friends in outdoor areas and then riding on a scooter, having sex after drinking a lot or taking a drug; mixing prescription drugs with alcohol.

Indicator 9: Behavior under the influence of drugs. The variables encompassed by this factor are the following: selling hashish or other drugs, mixing a lot of drugs some weekends, taking too much of some drug and losing consciousness, some drugs help me to not gain weight, driving a scooter after using hashish or other drugs.

In both indicators the scores were as follows: 0 indicates no risk exposure; 1 indicates low risk; 2 moderately low risk; 3 moderately high risk; 4 high risk and 5 very high risk.

\section{AnALYSIS}

To attain the final results of the study, the following statistical techniques were applied:

a) Factor Analysis, to reduce the initial number of variables to a smaller number of factors or dimensions that reveal the interdependence among the variables. Principal Components analysis was used, keeping in mind the statistics indicative of sampling adequacy and the suitability of such an analysis (KMO, Determinant, and Bartlett's test of sphericity).

b) The equality or homogeneity among groups was confirmed by the application of the non-parametric Kruskall-Wallis test when more than two groups were to be tested, and of the non-parametric Mann-Whitney test when testing only two groups. Non-parametric tests were deemed appropriate because all the cases involved ordinal variables. Differences in terms of sex, ethnic self-identification, economic perception and grade were tested and found to exist in the nine risk indicators established. Also, significant 
differences in terms of the nine indicators were confirmed in the four risk profiles established. Significant differences among the profiles in terms of sex, ethnic group, economic perception and grade were also found to exist.

c) Cluster analysis, the objective of which was to classify a number of elements in a series of groups in such a way that the similarities among the individuals of each group were as great as possible and the differences from group to group were as large as possible (homogeneity within, heterogeneity without). In this way, each cluster would correspond to a profile or certain type of behavior. A cluster analysis was conducted on the nine risk indicators found, yielding four different risk profiles. In order to test the stability and replicability of the cluster, some random subsamples were taken and another cluster analysis was performed on them, producing similar results and no significant differences. The results were then tested with measures of association, which yielded values that were highly significant and an intensity of association that was almost perfect.

d) Contingency analysis (using $x^{2}$ as the independence statistic) and multiple correspondence analysis (perceptual map) were used to study the association between sex, ethnicity, economic perception and grade.

\section{RESULTS}

\section{Sociodemographic characteristics of the sample}

The mean age of the students was 14.81 ( $S D=1.299)$, the median age being 15 , in an interval of 13 to $18.49 .1 \%$ of the students were male and $49.9 \%$ female ( $1 \%$ did not specify). Of them, $90 \%$ were born in Spain, $5.5 \%$ in Latin America, $0.7 \%$ in North Africa, $0.2 \%$ in sub-Saharan Africa, $0.5 \%$ in Asia, $0.7 \%$ in Eastern Europe, and $0.5 \%$ in Western Europe or the United States. $1.9 \%$ did not specify. As for the respondents' parents, $86.5 \%$ of their fathers and $85 \%$ of their mothers had also been born in Spain. The mean number of people (not including the student) living in the household was 3.25 (SD=1.211), the median and the mode being 3 people in an interval of 1 to 17 . The economic situation perceived by the students at home was as follows: $76.5 \%$ perceived a good economic situation, $19.5 \%$ perceived that the household had problems making ends meet and $1.6 \%$ perceived serious economic difficulties.

When the students were asked to mark the ethnic group they belonged to, $77.7 \%$ chose "White" and $16.6 \%$ chose "Other" groups (9\% Latin American, $1.9 \%$ black or mixed race, $0.2 \%$ Indian, $1 \%$ Asian, $0.9 \%$ North African, 3.7\% Gypsy, 3\% other). $5.7 \%$ did not mark a group or did so incorrectly. 
Table 1.

Measures of risk by sex, ethnicity, economic perception and grade

\begin{tabular}{|c|c|c|c|c|c|c|c|c|c|c|}
\hline & \multirow[b]{2}{*}{$n$} & \multirow[b]{2}{*}{$\%$} & \multicolumn{2}{|c|}{ Sex } & \multicolumn{2}{|c|}{ Ethnic } & \multicolumn{2}{|c|}{ EP } & \multicolumn{2}{|c|}{ Grade $^{11}$} \\
\hline & & & $\hat{0}$ & q & White & Other & Bad & Good & $\begin{array}{c}1^{\text {st }} \\
-2^{\text {nd }}\end{array}$ & $\begin{array}{l}3^{\text {rd }} \\
-4^{\text {th }}\end{array}$ \\
\hline $\begin{array}{l}\text { 11. Sexual activity } \\
\text { 0. Has never had sex } \\
\text { 1. Has always used contraception } \\
\text { 2. Has almost always used cont. } \\
\text { 3. Has sometimes used cont. } \\
\text { 4. Has hardly ever used cont. } \\
\text { 5. Has never used cont. }\end{array}$ & $\begin{array}{r}3,165 \\
477 \\
117 \\
72 \\
23 \\
35\end{array}$ & $\begin{array}{r}81.3 \\
12.3 \\
3.0 \\
1.8 \\
0.7 \\
0.9\end{array}$ & $\begin{array}{r}81.3 \\
12.5 \\
3.1 \\
1.9 \\
0.5 \\
0.8\end{array}$ & $\begin{array}{r}81.4 \\
11.9 \\
3.0 \\
1.8 \\
0.9 \\
1.0\end{array}$ & $\begin{array}{r}84.0 \\
11.1 \\
2.4 \\
1.4 \\
0.7 \\
0.6\end{array}$ & $\begin{array}{r}68.5 \\
17.5 \\
6.5 \\
4.4 \\
0.9 \\
2.2\end{array}$ & $\begin{array}{r}72.4 \\
17.2 \\
4.3 \\
3.1 \\
1.2 \\
1.8\end{array}$ & $\begin{array}{r}83.7 \\
10.9 \\
2.7 \\
1.5 \\
0.6 \\
0.7\end{array}$ & $\begin{array}{r}90.2 \\
6.1 \\
1.6 \\
1.3 \\
0.3 \\
0.6\end{array}$ & $\begin{array}{r}72.6 \\
18.2 \\
4.4 \\
2.4 \\
1.1 \\
1.2\end{array}$ \\
\hline$p$-value & & & \multicolumn{2}{|c|}{0.912} & \multicolumn{2}{|c|}{0.000} & \multicolumn{2}{|c|}{0.000} & \multicolumn{2}{|c|}{0.000} \\
\hline $\begin{array}{l}\text { 12. Legal drugs } \\
\text { 0. Has never used } \\
\text { 1. Has used alcohol or another drug once or twice a year } \\
\text { 2. Has used alcohol or another drug 2-3 times/month } \\
\text { 3. Has used alcohol or other drugs } 2-3 \text { times/week } \\
\text { 4. Has used alcohol or other drugs only on weekends } \\
\text { 5. Uses alcohol or drugs daily }\end{array}$ & $\begin{array}{r}844 \\
1,134 \\
435 \\
242 \\
574 \\
661\end{array}$ & $\begin{array}{r}21.6 \\
29.0 \\
11.6 \\
6.2 \\
14.7 \\
16.9\end{array}$ & $\begin{array}{r}24.1 \\
29.5 \\
11.4 \\
5.9 \\
14.1 \\
14.9\end{array}$ & \begin{tabular}{|r|}
19.1 \\
28.5 \\
11.9 \\
6.4 \\
15.1 \\
19.0
\end{tabular} & $\begin{array}{r}22.0 \\
31.1 \\
11.4 \\
5.4 \\
14.7 \\
15.4\end{array}$ & $\begin{array}{r}17.8 \\
21.0 \\
12.4 \\
9.6 \\
15.1 \\
24.1\end{array}$ & \begin{tabular}{r|}
15.0 \\
25.7 \\
12.2 \\
7.8 \\
16.2 \\
23.0
\end{tabular} & \begin{tabular}{r|}
23.2 \\
30.0 \\
11.4 \\
5.7 \\
14.3 \\
15.3
\end{tabular} & $\begin{array}{r}31.0 \\
33.6 \\
9.1 \\
5.2 \\
10.1 \\
11.0\end{array}$ & $\begin{array}{r}12.6 \\
24.5 \\
14.0 \\
7.1 \\
19.1 \\
22.6\end{array}$ \\
\hline $\mathrm{p}$-value & & & \multicolumn{2}{|c|}{0.000} & \multicolumn{2}{|c|}{0.000} & \multicolumn{2}{|c|}{0.000} & \multicolumn{2}{|c|}{0.000} \\
\hline $\begin{array}{l}\text { 13. Illegal drugs } \\
\text { 0. Has never used } \\
\text { 1. Has used a drug once or twice a year } \\
\text { 2. Has used a drug } 2-3 \text { times/month } \\
\text { 3. Has used a drug } 2-3 \text { times/week } \\
\text { 4. Has used drugs only on weekends } \\
\text { 5. Uses drugs daily }\end{array}$ & \begin{tabular}{|r|}
3,329 \\
83 \\
11 \\
5 \\
12 \\
11
\end{tabular} & $\begin{array}{r}96.5 \\
2.4 \\
0.3 \\
0.1 \\
0.3 \\
0.3\end{array}$ & $\begin{array}{r}96.0 \\
2.8 \\
0.4 \\
0.1 \\
0.4 \\
0.4\end{array}$ & $\begin{array}{r}96.9 \\
2.1 \\
0.2 \\
0.2 \\
0.3 \\
0.3\end{array}$ & $\begin{array}{r}97.0 \\
2.1 \\
0.3 \\
0.1 \\
0.2 \\
0.3\end{array}$ & $\begin{array}{r}93.3 \\
3.9 \\
0.4 \\
0.4 \\
1.3 \\
0.4\end{array}$ & $\begin{array}{r}94.0 \\
3.5 \\
0.4 \\
0.3 \\
0.4 \\
0.5\end{array}$ & $\begin{array}{r}96.9 \\
2.1 \\
0.3 \\
0.1 \\
0.3 \\
0.3\end{array}$ & $\begin{array}{r}97.5 \\
1.5 \\
0.1 \\
0.2 \\
0.3 \\
0.4\end{array}$ & $\begin{array}{r}95.4 \\
3.3 \\
0.5 \\
0.1 \\
0.4 \\
0.2\end{array}$ \\
\hline $\mathrm{p}$-value & & & \multicolumn{2}{|c|}{0.141} & \multicolumn{2}{|c|}{0.000} & \multicolumn{2}{|c|}{0.009} & \multicolumn{2}{|c|}{0.001} \\
\hline $\begin{array}{l}\text { 14. Fighting during last year } \\
\text { 0. Has never fought } \\
\text { 1. Once } \\
\text { 2. } 2-3 \text { times } \\
\text { 3. } 4-5 \text { times } \\
\text { 4. } 6-8 \text { times } \\
\text { 5. More than } 8 \text { times }\end{array}$ & $\begin{array}{r}3,001 \\
323 \\
365 \\
106 \\
47 \\
34\end{array}$ & $\begin{array}{r}77.4 \\
8.3 \\
9.4 \\
2.7 \\
1.2 \\
0.9\end{array}$ & $\begin{array}{r}68.4 \\
10.5 \\
13.8 \\
4.0 \\
1.7 \\
1.5\end{array}$ & $\begin{array}{r}86.2 \\
6.2 \\
5.2 \\
1.4 \\
0.7 \\
0.3\end{array}$ & $\begin{array}{r}80.0 \\
7.7 \\
8.4 \\
2.2 \\
1.1 \\
0.6\end{array}$ & $\begin{array}{r}65.3 \\
10.7 \\
14.5 \\
5.5 \\
2.0 \\
2.0\end{array}$ & $\begin{array}{r}71.1 \\
9.7 \\
12.4 \\
3.5 \\
2.3 \\
1.0\end{array}$ & $\begin{array}{r}79.2 \\
8.0 \\
8.7 \\
2.5 \\
0.9 \\
0.8\end{array}$ & $\begin{array}{r}74.9 \\
8.8 \\
10.2 \\
3.6 \\
1.5 \\
1.0\end{array}$ & $\begin{array}{r}79.9 \\
7.8 \\
8.7 \\
1.8 \\
1.0 \\
0.8\end{array}$ \\
\hline$p$-value & & & \multicolumn{2}{|c|}{0.000} & \multicolumn{2}{|c|}{0.000} & \multicolumn{2}{|c|}{0.000} & \multicolumn{2}{|c|}{0.000} \\
\hline $\begin{array}{l}\text { 15. Riding/Driving on drugs } \\
\text { 0. Never } \\
\text { 1. Rarely } \\
\text { 2. Sometimes } \\
\text { 3. Often } \\
\text { 4. Very often } \\
\text { 5. Always or almost always }\end{array}$ & $\begin{array}{r}2,515 \\
735 \\
285 \\
107 \\
43 \\
14\end{array}$ & $\begin{array}{r}68.0 \\
19.9 \\
7.7 \\
2.9 \\
1.2 \\
0.4\end{array}$ & $\begin{array}{r}66.5 \\
19.4 \\
8.0 \\
4.0 \\
1.4 \\
0.7\end{array}$ & $\begin{array}{r}69.3 \\
20.5 \\
7.4 \\
1.8 \\
0.9 \\
0.1\end{array}$ & $\begin{array}{r}69.1 \\
20.2 \\
7.0 \\
2.4 \\
1.1 \\
0.3\end{array}$ & $\begin{array}{r}63.3 \\
19.3 \\
9.8 \\
4.5 \\
2.1 \\
1.0\end{array}$ & \begin{tabular}{|r|}
56.2 \\
26.8 \\
11.1 \\
3.8 \\
1.8 \\
0.4
\end{tabular} & \begin{tabular}{|r|}
71.2 \\
17.9 \\
6.9 \\
2.6 \\
1.0 \\
0.4
\end{tabular} & $\begin{array}{r}76.2 \\
15.3 \\
5.6 \\
1.6 \\
0.9 \\
0.3\end{array}$ & $\begin{array}{r}60.2 \\
24.2 \\
9.7 \\
4.1 \\
1.4 \\
0.4\end{array}$ \\
\hline$p$-value & & & 0.0 & & 0.0 & 01 & 0.0 & & 0.0 & \\
\hline
\end{tabular}


Table 1.

Cont.

\begin{tabular}{|c|c|c|c|c|c|c|c|c|c|c|}
\hline & & & $\mathrm{Se}$ & $e x$ & Eth & inic & $E$ & & Gra & $\mathrm{de}^{11}$ \\
\hline & $\mathrm{n}$ & $\%$ & $\hat{\sigma}$ & 우 & White & Other & Bad & Good & $\begin{array}{c}1^{\text {st }} \\
-2^{\text {nd }}\end{array}$ & $\begin{array}{c}3^{\text {rd }} \\
-4^{\text {th }}\end{array}$ \\
\hline $\begin{array}{l}\text { 16. Recklessness on the road } \\
0 . \text { Never } \\
\text { 1. Rarely } \\
\text { 2. Sometimes } \\
\text { 3. Often } \\
\text { 4. Very often } \\
\text { 5. Always or almost always }\end{array}$ & $\begin{array}{r}743 \\
1,158 \\
932 \\
488 \\
262 \\
176\end{array}$ & \begin{tabular}{|r|}
19.8 \\
30.8 \\
24.8 \\
13.0 \\
7.0 \\
4.7
\end{tabular} & $\begin{array}{r}15.5 \\
27.0 \\
26.0 \\
15.4 \\
9.4 \\
6.7\end{array}$ & $\begin{array}{r}23.9 \\
34.4 \\
23.7 \\
10.6 \\
4.7 \\
2.7\end{array}$ & $\begin{array}{r}19.8 \\
32.3 \\
25.0 \\
12.8 \\
6.1 \\
4.0\end{array}$ & $\begin{array}{r}19.9 \\
24.5 \\
24.3 \\
12.1 \\
11.4 \\
7.9\end{array}$ & \begin{tabular}{|r|}
13.1 \\
28.1 \\
28.8 \\
14.7 \\
9.3 \\
6.0
\end{tabular} & $\begin{array}{r}21.5 \\
31.6 \\
23.6 \\
12.5 \\
6.4 \\
4.3\end{array}$ & $\begin{array}{r}26.9 \\
30.6 \\
21.9 \\
10.7 \\
5.7 \\
4.3\end{array}$ & $\begin{array}{r}13.0 \\
31.1 \\
27.6 \\
15.1 \\
8.2 \\
5.0\end{array}$ \\
\hline$p$-value & & & 0.0 & 000 & 0.0 & & 0.0 & 000 & & 00 \\
\hline $\begin{array}{l}\text { 17. Lack of safety on the road } \\
0 . \text { Never } \\
\text { 1. Rarely } \\
\text { 2. Sometimes } \\
\text { 3. Often } \\
\text { 4. Very often } \\
\text { 5. Always or almost always }\end{array}$ & $\begin{array}{r}1,420 \\
1,009 \\
573 \\
501 \\
65 \\
37\end{array}$ & \begin{tabular}{|r|}
39.4 \\
28.0 \\
15.9 \\
13.9 \\
1.8 \\
1.0
\end{tabular} & $\begin{array}{r}37.9 \\
30.1 \\
15.2 \\
13.7 \\
1.8 \\
1.3\end{array}$ & $\begin{array}{r}40.9 \\
25.9 \\
16.6 \\
14.0 \\
1.9 \\
0.7\end{array}$ & $\begin{array}{r}41.6 \\
29.1 \\
15.1 \\
12.4 \\
1.3 \\
0.5\end{array}$ & $\begin{array}{r}29.5 \\
24.1 \\
18.1 \\
21.4 \\
3.9 \\
3.1\end{array}$ & \begin{tabular}{|r|}
32.8 \\
25.7 \\
21.0 \\
16.7 \\
2.3 \\
1.4
\end{tabular} & \begin{tabular}{|r|}
41.2 \\
28.7 \\
14.4 \\
13.2 \\
1.6 \\
0.9
\end{tabular} & $\begin{array}{r}42.6 \\
27.2 \\
13.5 \\
13.4 \\
1.7 \\
1.7\end{array}$ & $\begin{array}{r}36.4 \\
28.7 \\
18.1 \\
14.4 \\
1.9 \\
0.4\end{array}$ \\
\hline$p$-value & & & 0.3 & 370 & 0.0 & & 0.0 & 000 & & 00 \\
\hline $\begin{array}{l}\text { 18. Behavior under the influence of alcohol } \\
0 . \text { Never } \\
\text { 1. Rarely } \\
\text { 2. Sometimes } \\
\text { 3. Often } \\
\text { 4. Very often } \\
\text { 5. Always or almost always }\end{array}$ & \begin{tabular}{|r|}
2,394 \\
727 \\
423 \\
204 \\
82 \\
12
\end{tabular} & \begin{tabular}{|r|}
62.3 \\
18.9 \\
11.0 \\
5.3 \\
2.1 \\
0.3
\end{tabular} & $\begin{array}{r}64.4 \\
18.0 \\
9.9 \\
5.0 \\
2.3 \\
0.5\end{array}$ & $\begin{array}{r}60.3 \\
19.8 \\
12.1 \\
5.7 \\
2.0 \\
0.1\end{array}$ & $\begin{array}{r}63.2 \\
19.3 \\
10.4 \\
4.8 \\
2.0 \\
0.2\end{array}$ & $\begin{array}{r}57.0 \\
18.9 \\
12.6 \\
7.8 \\
2.8 \\
0.8\end{array}$ & \begin{tabular}{|r|}
53.8 \\
22.4 \\
13.6 \\
6.1 \\
3.6 \\
0.5
\end{tabular} & \begin{tabular}{|r|}
64.6 \\
17.9 \\
10.3 \\
5.1 \\
1.8 \\
0.3
\end{tabular} & $\begin{array}{r}79.0 \\
11.9 \\
5.4 \\
2.2 \\
1.2 \\
0.2\end{array}$ & $\begin{array}{r}46.3 \\
25.7 \\
16.4 \\
8.3 \\
3.0 \\
0.4\end{array}$ \\
\hline$p$-value & & & 0.0 & 15 & 0.0 & & 0.0 & 000 & & 00 \\
\hline $\begin{array}{l}\text { 19. Behavior under the influence of drugs } \\
0 . \text { Never } \\
\text { 1. Rarely } \\
\text { 2. Sometimes } \\
\text { 3. Often } \\
\text { 4. Very often } \\
\text { 5. Always or almost always }\end{array}$ & $\begin{array}{r}3,485 \\
227 \\
78 \\
37 \\
11 \\
6\end{array}$ & $\begin{array}{r}90.7 \\
5.9 \\
2.0 \\
1.0 \\
0.3 \\
0.2\end{array}$ & $\begin{array}{r}89.3 \\
6.0 \\
2.7 \\
1.4 \\
0.4 \\
0.2\end{array}$ & $\begin{array}{r}92.0 \\
5.7 \\
1.4 \\
0.5 \\
0.2 \\
0.2\end{array}$ & $\begin{array}{r}91.4 \\
5.8 \\
1.6 \\
0.9 \\
0.2 \\
0.1\end{array}$ & $\begin{array}{r}87,4 \\
6,7 \\
4,0 \\
1,0 \\
0,7 \\
0,3\end{array}$ & \begin{tabular}{|r|}
88,1 \\
6,5 \\
3,9 \\
1,0 \\
0,2 \\
0,2
\end{tabular} & \begin{tabular}{|r|}
91,3 \\
5,8 \\
1,5 \\
1,0 \\
0,3 \\
0,1
\end{tabular} & $\begin{array}{r}94,8 \\
3,2 \\
1,0 \\
0,5 \\
0,2 \\
0,3\end{array}$ & $\begin{array}{r}86,7 \\
8,5 \\
3,0 \\
1,4 \\
0,4 \\
0,1\end{array}$ \\
\hline$p$-value & & & 0.0 & 03 & 0.0 & & 0.0 & 004 & & 00 \\
\hline
\end{tabular}

Source: Elaborated Data from Researchers.

\section{Results of the measures of risk}

Table 1 shows the results obtained (frequencies and percentages) from the nine risk indicators developed, and also the differences in sex, ethnic self-identification, econo- 
mic perception and grade. Among the risk indicators set forth, two which reach a higher percentage in the situation of maximum risk (5) should be highlighted: the use of legal drugs (16.9\%) and behaviors involving recklessness on the road (4.7\%). In practically all the measures we found significant differences in the variables considered, except in the indicator of sexual activity, the use of illegal drugs and the indicator of lack of safety on the road, which in all three cases do not show significant differences according to sex.

\section{Risk profiles}

The cluster analysis performed on the 9 indicators discussed above yielded four profiles. This number was deemed to be sufficiently significant and to show clear differences among groups.

Table 2.

Mean and standard deviation of the indicators by risk profile

\begin{tabular}{|l|c|c|c|c|c|}
\hline Risk Indicators & Total & $\begin{array}{c}\text { Profile 1 } \\
\text { Low Risk }\end{array}$ & $\begin{array}{c}\text { Profile 2 } \\
\text { Moderate Risk }\end{array}$ & $\begin{array}{c}\text { Profile 3: } \\
\text { Moderate Risk, High } \\
\text { in Legal Drugs }\end{array}$ & $\begin{array}{c}\text { Profile 4 } \\
\text { High Risk }\end{array}$ \\
\hline I1. sexual activity & 0.31 & $0.05^{2,3,4}$ & $0.28^{1,3,4}$ & $0.30^{1,2,4}$ & $1.13^{1,2,3}$ \\
& $(0.81)$ & $(0.27)$ & $(0.76)$ & $(0.64)$ & $(1.33)$ \\
\hline 12. legal drugs & 2.14 & $.73^{2,3,4}$ & $1.13^{1,3,4}$ & $4.19^{1,2,4}$ & $4.38^{1,2,3}$ \\
& $(1.82)$ & $(0.68)$ & $(0.75)$ & $(0.74)$ & $0.82)$ \\
\hline 13. illegal drugs & 0.07 & $.005^{2,3,4}$ & $0.03^{1,3,4}$ & $0.08^{1,2,4}$ & $0.25^{1,2,3}$ \\
& $(0.43)$ & $(0.16)$ & $(0.27)$ & $(0.51)$ & $(0,76)$ \\
\hline 14. physical fight & 0.45 & $0.14^{2,3,4}$ & $0.53^{1,3,4}$ & $0.39^{1,2,4}$ & $1.17^{1,2,3}$ \\
& $0.96)$ & $(0.49)$ & $(1.03)$ & $(0.84)$ & $(1.33)$ \\
\hline 15. riding/ driving on drugs & 1.71 & $0.74^{2,3,4}$ & $2.36^{1,3,4}$ & $1.57^{1,2,4}$ & $3.60^{1,2,3}$ \\
& $(1.36)$ & $(0.69)$ & $(1.03)$ & $(0.98)$ & $(1.10)$ \\
\hline 16. recklessness on the road & 0.50 & $0.12^{2,3,4}$ & $0.55^{1,3,4}$ & $0.33^{1,2,4}$ & $1.62^{1,2,3}$ \\
& $(0.89)$ & $(0.36)$ & $(0.79)$ & $(0.56)$ & $(1.16)$ \\
\hline 17. lack of safety on the road & 1.14 & $0.48^{2,3,4}$ & $1.68^{1,3,4}$ & $0.95^{1,2,4}$ & $1.92^{1,2,3}$ \\
& $(1.19)$ & $(0.72)$ & $(1.15)$ & $(1.1)$ & $(1.13)$ \\
\hline I8. behavior under the influence & 0.67 & $0.11^{2,3,4}$ & $0.53^{1,3,4}$ & $0.72^{1,2,4}$ & $2.41^{1,2,3}$ \\
of alcohol & $(1.04)$ & $(0.36)$ & $(0.77)$ & $(0.82)$ & $(1.10)$ \\
\hline I9. behavior under the influence & 0.15 & $0.01^{2,3,4}$ & $0.05^{1,3,4}$ & $0.07^{1,2,4}$ & $0.76^{1,2,3}$ \\
of drugs & $(0.54)$ & $(0.10)$ & $(0.31)$ & $(0.27)$ & $(1.10)$ \\
\hline N & 2715 & 1064 & 640 & 649 & 362 \\
& & $(39 \%)$ & $(24 \%)$ & $(24 \%)$ & $(13 \%)$ \\
\hline Mean sum of indicators & & 2.39 & 7.14 & 8.60 & 17.25 \\
& & $(1.50)$ & $(2.54)$ & $(2.65)$ & $(4.08)$ \\
\hline
\end{tabular}

${ }^{1}$ Profile different from Profile $1(p \leq 0.05)$

2Profile different from Profile $2(p \leq 0.05)$

${ }^{3}$ Profile different from Profile $3(p \leq 0.05)$

${ }^{4}$ Profile different from Profile $4(p \leq 0.05)$

Source: Elaborated Data from Researchers. 
Figure 1.

Profiles and Indicators of Risk

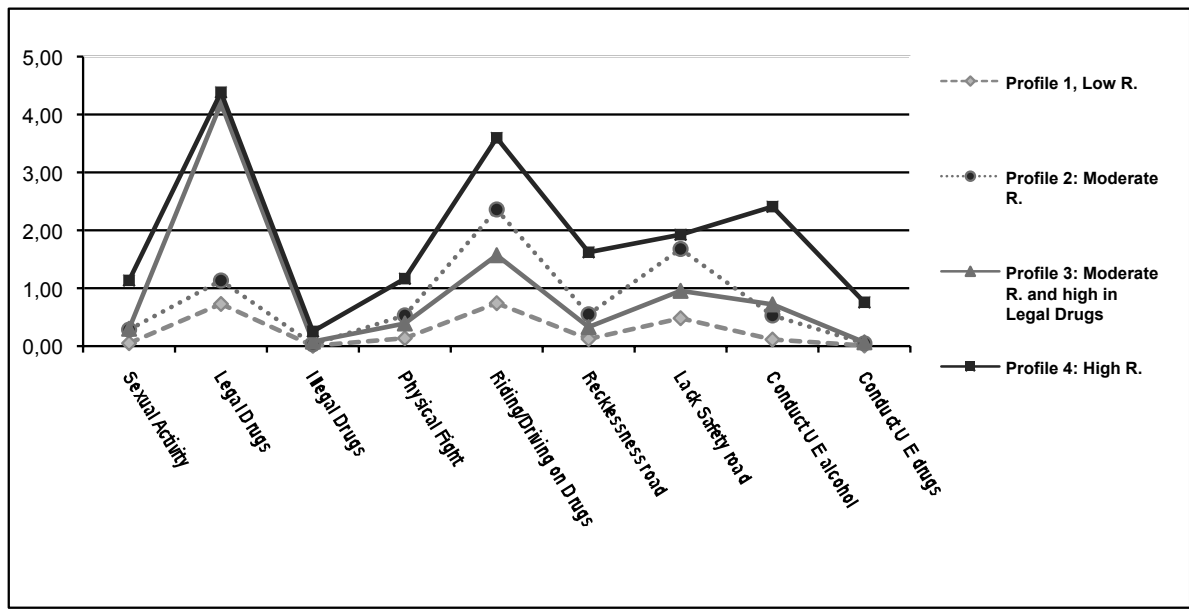

Source: Elaborated Data from Researchers.

Figure 1 and Table 2 present the overall mean value of each indicator, as well as its value and mean weight in each profile, along with the corresponding standard deviations. The equality of distributions of the indicators in the four profiles was tested using the nonparametric Kruskall-Wallis test for comparison of all groups, and the Mann-Whitney test in two-by-two comparisons. Significant differences were obtained with a confidence level of $95 \%$ among all the groups for all the indicators considered. Table 2 also adds up the risk indicators for each profile and estimates the mean value and its standard deviation, thus making it possible to obtain a ranking of overall risk among the four profiles considered. Each of the profiles found is described below.

Profile 1. This is the most numerous profile as $39 \%$ of the young people fall into this category. That is, it is probable that a given young person will belong to this profile, which is characterized by being a low-risk profile as all the indicators have the lowest mean values.

Profile 2. This profile has a moderate level of risk in almost all the indicators. The overall mean score is 7.14. Most of these indicators have a mean value of less than 1 , although the indicators of alcohol and illegal drugs, along with bad habits related to road safety, have a mean between 1 and 2 . In addition, the indicator that reflects the degree of recklessness of young people has a mean value of 2.36. This profile has a moderate level of risk and the lowest mean score after Profile 1. Profile 2 mostly comprises young 
people with behavior that is worrying in terms of road safety. This group displays the second most reckless behavior and has the worst habits in terms of safety measures such as wearing helmets or seatbelts while riding on scooters or in cars. This group includes $24 \%$ of the adolescents, that is, one out of four young people would fall into this profile.

Profile 3. This is a profile of moderate risk as most of the indicators have a mean value of less than 1. Only the degree of recklessness is situated between 1 and 2 . What stands out most about this profile is the high score of the risk indicator related to the use of alcohol and legal drugs by young people, which has a mean value of 4.19. The overall mean value, which corresponds to the sum of all the indicators, is 8.6. This is the second highest mean value, although it remains far from that of Profile 4 , which is the profile with greatest risk and is discussed below. Profile 3 includes $24 \%$ of the adolescents. Approximately one out of 4 adolescents are classified in this group of moderate risk, but which has a high degree of risk in terms of alcohol and legal drugs; substances that are easily accessible and which young people frequently experiment with.

Profile 4. This profile comprises young people who show a higher level of risk as the overall mean value is 17.25; a much higher mean value than those of the other profiles. This profile has the highest mean values in all of the indicators. The only indicator with a mean value of less than 1 is that concerning the use of illegal drugs. This indicator obtained very low values in all cases. Of special interest among the rest of the indicators is, again, the use of alcohol and legal drugs and the degree of recklessness, both of which have mean values greater than 3, and also Indicator 8 , which has a mean value greater than $2.13 \%$ of the adolescents belong to this profile, which means that approximately one out of ten young people are exposed to a high level of risk.

\section{Demographic differences among the profiles}

To explore the differences among the risk profiles, table 3 shows a comparison of the behavior of four demographic characteristics, specifically sex, ethnicity, economic perception and grade. If we focus our attention on the two most extreme profiles, that of highest risk (Profile 4) and that of lowest risk (Profile 1), we see that there are significant differences in terms of the aforementioned demographic characteristics. The highest risk profile has the greatest balance between males and females $(51 \%$ and $49 \%$, respectively), the highest percentage of non-whites $(27 \%)$, the highest percentage of young people who perceive a bad economic situation at home (32\%), and the highest percentage of students in higher grades (3 out of 4 ).

Profile 1, the lowest risk profile, has a higher percentage of women than men, although it is not the group or profile with the greatest percentage of women, which is Profile 3. In this profile, the use of alcohol and legal drugs predominates, it has the hig- 
Table 3.

$\%$ of demographic variables by risk profile

\begin{tabular}{l|l|lclll}
\hline $\begin{array}{l}\text { Variables } \\
\text { demográficas }\end{array}$ & & Total & Profile 1 & Profile 2 & Profile 3 & Profile 4 \\
\hline Sex & Male & 49.6 & $44.9^{23,4}$ & $57.6^{1,3,4}$ & $40.1^{1,2,4}$ & $51.1^{1,2,3}$ \\
& Female & 50.4 & 55.1 & 42.4 & 59.9 & 48.9 \\
\hline Ethnicity & White & 82.4 & $89.1^{23,4}$ & $84.6^{3,4}$ & $83.9^{2,4}$ & $72.8^{1,2,3}$ \\
& Other & 17.6 & 10.9 & 15.4 & 16.1 & 27.2 \\
\hline Economic & Bad & 21.7 & $15.6^{23,4}$ & $23.8^{3,4}$ & $23.6^{2,4}$ & $32.2^{1,2,3}$ \\
Perception & Good & 78.3 & 84.4 & 76.2 & 76.4 & 67.8 \\
\hline Grade in ESO & $1_{\mathrm{st}}-2_{\text {nd }}$ & 49.9 & $59.9^{2,3,4}$ & $47.3^{1,3,4}$ & $37.2^{2,4}$ & $26.0^{1,2,3}$ \\
& $3_{\text {rd }}-4_{\text {th }}$ & 50.1 & 40.1 & 52.7 & 62.8 & 74.0 \\
\hline
\end{tabular}

${ }^{1}$ Profile different from Profile $1(p \leq 0.05)$

${ }^{2}$ Profile different from Profile $2(p \leq 0.05)$

${ }^{3}$ Profile different from Profile $3(p \leq 0.05)$

${ }^{4}$ Profile different from Profile $4(p \leq 0.05)$

Source: Elaborated Data from Researchers.

hest percentage of whites $(89 \%)$ and also of respondents who perceive a good economic situation at home $(84 \%)$, as well as a greater concentration of young people from the lower grades or who are younger.

Profile 2 contains a higher percentage of males and is associated with a greater risk of recklessness and bad driving habits.

If we place the variables on a perceptual map using Multiple Correspondence Analysis, it is easier to comprehend the relationships among the categories corresponding to the variables involved (figure 2). In the upper right-hand quadrant a strong association can be observed between Profile 4 (the highest risk profile), the ethnic group Other, and a bad economic perception. Moreover, the nearby lower right-hand quadrant contains the age group or the last two grades of the compulsory secondary education cycle. Summing up, it is apparent that greater risk is closely associated with a bad economic situation, the ethnic group Other and higher grades. A strong association can also be seen between being male and Profile 2, which is where reckless behavior and bad driving habits are notable. Also worthy of note is the fact that adolescents who identified themselves as White are strongly associated with a good economic perception and with Profile 1, which has the lowest risk. And finally, being 
Figure 2.

Perceptual Map about Risk Profile and Demographic Data

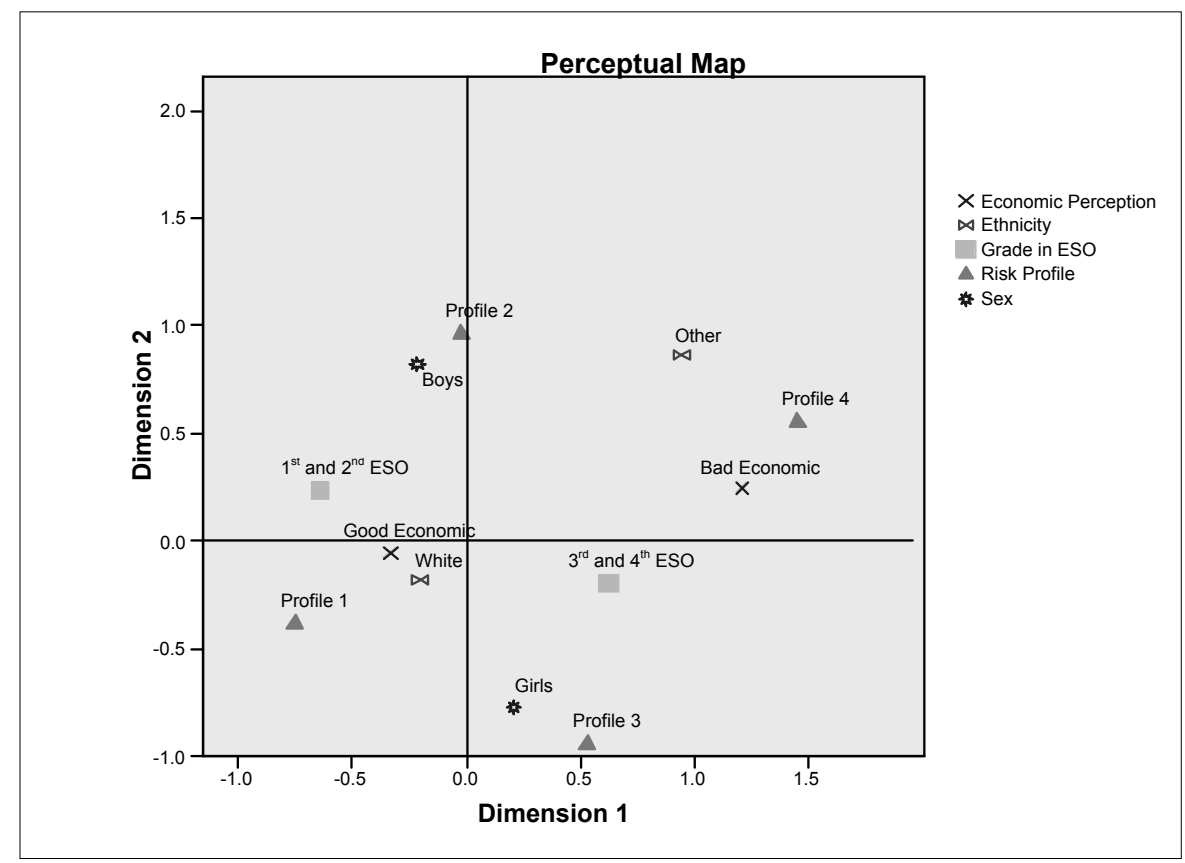

Source: Elaborated Data from Researchers.

female is seen to be closely associated with Profile 3 , which is where the use of alcohol and legal drugs predominates.

\section{Discussion}

This study is among the very few performed in Spain (Carrasco, 2002) on co-occurrence of risk behaviors and it contributes to a better understanding of the conduct that puts the health of Spanish adolescents at risk. First of all, the results of the study highlight that co-occurrence of risk behaviors in Spanish adolescents is concentrated in a small group $(13 \%)$. Graham suggested that the number of adolescents that display problematic risk behavior was one out of five. This study suggests that the number is much lower; one out of ten. Most adolescents do not display a pattern of multiple risk behaviors as found in some studies conducted in other countries (Brener and Collins 1998; Zweig et al. 2001; Zweig et al. 2002; Graham 2004; Baskin-Sommers and Sommers 2006). Behavior invol- 
ving the use of legal drugs (tobacco, alcohol and cannabis) and actions performed under the influence of these drugs, especially driving scooters or mopeds, are those that most stand out in the highest risk profile and to a lesser degree in profiles 2 and 3 , which are of moderate risk. This may be due to the fact that the use of these drugs among Spanish adolescents is related to social norms and that their use was tolerated to a certain extent until recent years. Although access to tobacco and alcohol has been restricted for people under the age of 18, these psychoactive substances are still widely considered to be of low risk and are quite easily accessible (PNSD 2007). Also, as put forward by Brener and Collins (1998), it may be that some risk behaviors such as tobacco or alcohol use do not decrease with age but rather continue, and are then joined by new risk behaviors, which would explain the increase in risky conduct. It is important to highlight that no differences in sex are found in this profile, which may indicate that with regard to the co-occurrence of behaviors the two sexes are becoming more equal, as suggested by Gibbons et al. (1989).

Secondly, unlike the findings of Zweig et al. (2001), our results indicate that sociodemographic characteristics do serve to explain some of the differences found among the profiles. The multiple correspondence analysis shows that the highest risk profile is associated with a bad economic perception, being in a higher grade and belonging to the ethnic group "Other".

Thirdly, we have found important differences between the sexes. Girls belong to a lower risk profile. However, girls stand out in the terms of the use of legal drugs (tobacco and alcohol), thus confirming a phenomenon that has become apparent in recent surveys on drug use in Spain (Romo 2001; NPD 2007). It should also be highlighted that boys show more reckless behavior and take higher risks when driving; a finding that should be taken into account in prevention efforts.

Fourth, it is worth noting the differences in terms of ethnicity that are found in the risk behaviors and in the profiles established. Our results do not confirm that belonging to an ethnic minority serves as a protection factor against the co-occurrence of risk behaviors as Marsiglia et al. (2008) have suggested. The respondents who identified themselves as belonging to "other" ethnic groups show a greater risk profile, standing out from the other respondents in four of the risk behaviors studied (sexual activity, use of legal or tolerated drugs, violence, recklessness and lack of safety practices on the road). We could hypothesize that for the group of adolescents from other countries, participating in different risk behaviors is a way to integrate with Spanish adolescents. However, this interpretation may not be pertinent in the case of gypsy adolescents, who are Spanish. Their situation may be related to other risk behaviors such as school absenteeism, dropout or failure, which were not addressed in this work.

The results obtained have certain limitations. First, the information regarding risk behaviors was obtained by asking the adolescents to report on themselves, and it is thus difficult to know to what extent the behavior is under or overestimated. Second, this study is based on the adolescent population enrolled in school, and the results cannot be extrapolated to adolescents who are not part of the school system. Third, the sample 
used is comprised of two samples that are representative of two areas of Spain (central and southern), but not of the three geographical areas in which data was collected, nor of all Spanish adolescents. Therefore, we can only generalize the results in two of the three geographical areas in Spain that are used in this study. Fourth, the analyses conducted do not include protection factors so often discussed in the international literature, which might explain the reasons for the results obtained, or how these factors influence the risk behaviors. Five, risk conduct is dynamic and changeable, while the study performed is transversal. In this type of conduct longitudinal studies are also required, and can contribute to a better understanding of the appearance and elimination of the risk behaviors.

Based on our findings, we believe we can make the following recommendations to educational and health professionals: a) it is necessary to increase prevention efforts in groups showing different risk behaviors, paying special attention to age, sex and ethnicity. Since at this time Spain is a country that receives immigrants, it is especially important for prevention programs to take into consideration cultural and ethnic differences. The ethnic and sex differences observed lead us to the conclusion that prevention programs should not be homogenous or attempt to convey universal messages; b) prevention programs should include risk reduction features, which make it possible to reduce the damage and negative consequences that risky conduct has in adolescents. Once the use of tobacco and alcohol has begun, aiming at the elimination of this conduct may not be realistic, especially when the social context is permissive in this area. A better way to approach adolescents who already use these substances would be to attempt to mitigate the negative consequences that such conduct has on their health; $c$ ) awareness programs and preventive actions on the subject of road safety must be increased to prevent the Spanish youth of today from acquiring bad driving habits that continue into adulthood. Spain currently faces a serious problem of high death rates due to traffic accidents. Education and the prevention of bad driving habits is the best strategy for diminishing or eradicating such deaths; and d) it is important to raise awareness among professionals and the adolescents themselves of the relationship between risk behaviors and the consequences that they may have on young people's health and development. If a risk behavior is detected, it might be associated with others and early intervention may make it possible to avoid co-occurrence and increased risk.

\section{REFERENCES}

Alhájeme, A. and M. Martínez. 2004. "Estructura de edades, escolarización y tamaño de la población gitana asentada en España." Revista Española de Investigaciones Sociológicas 106:161-174.

Anderson, K.G., S.F. Tapert, I. Moadab, T.J. Crowley and S. A. Brown. 2007. "Personality risk profile for conduct disorder and substance use disorders in youth." Addictive Behaviors 32:2377-2382.

Arnett, J.J. 1992. "Reckless behaviour in adolescence: a developmental perspective." Developmental Review 12:339-373. 
Arnett, J.J. and L. Arnett. 1994. "Socialization and risk behavior in two countries: Denmark and United States." Youth and Society 26:3-22.

Baskin-Sommers, A. and I. Sommers. 2006. "The co-occurrence of substance use and high-risk behaviors." Journal of Adolescent Health 38:609-611.

Brener, N.D., and J.L. Collins. 1998. "Co-Occurrence of Health-Risk Behaviors Among Adolescents in the United States." Journal of Adolescent Health 22:209-213.

Brindis, C., Wolfe, A.L., Mccarter, V., Ball, S. and S. Starbuck-Morales. 1995. "The Associations Between Immigrant Status and Risk-Behavior Patterns in Latino Adolescents." Journal of Adolescence Health 17:99-105.

Byrnes J., Miller, D.C. and W. Schafer. 1999. "Gender differences in risk taking: A Meta-Analysis." Psychological Bulletin 125:367-383.

Carrasco, A.M. 2002. "Estilo de vida, consumo de alcohol y factores psicosociales asociados: un estudio en adolescentes." Revista de Psicología Social Aplicada 12:49-78.

Coleman, J. and A. Hagell. 2007. Adolescence, risk and resilience. Against the odds. Chichester West Sussex: John Wiley and Sons Ltd.

Cooper, M.L., V.B. Agocha and M.S. Sheldon. 2000. "A Motivational Perspective on Risky Behaviors: the Role of Personality and Affect Regulatory Processes." Journal of Personality 68:1059-1088.

Defensor del Pueblo. 2007 (Spanish Ombudsman). Violencia escolar: el maltrato entre iguales en la educación secundaria obligatoria. Madrid.

D.G.T. (National Traffic Administration of Spain). 2007. Anuario estadístico de accidentes 2006. Dirección General de Tráfico. Madrid. Ministerio del Interior. España.

Dolcini, M.M., L.D. Cohn, N.E. Adler, S.G. Millstein, C.E. Irwin, S.M. Kegeles and G.C. Stone. 1989. "Adolescent egocentrism and feelings of invulnerability." The Journal of Early Adolescence 9:409-418.

Dorius G., T. Heaton, and P. Steffen. 1993. "Adolescent life events and their association with the onset of sexual intercourse." Youth and Society 25:3-23.

Dworkin, J. 2005. "Risk Taking as Developmentally Appropriate Experimentation for College Students." Journal of Adolescent Research 20:219-241.

Eklund, J.M. and B.A. Klinteberg. 2005. "Personality Characteristics as Risk Indications of Alcohol Use and Violent Behavior in Male and Female Adolescents." Journal of Individual Differences 26:63-73.

Essau, C.A. 2004. "Risk-taking behaviour among German adolescents." Journal of Youth Studies. 7:499-512.

Fischhoff, B., E. Nightingale and J. lannotta (ed). 2001. Adolescent risk and vulnerability. Concepts and measurement. Washington, D.C.: National Academy Press. 
Flay, B.R. 2003. "Positive Youth development is necessary and possible." Pp.347-355 in Reducing adolescent risk. Toward an integrated approach edited by Romer D. Thousand Oaks, CA: Sage Publications.

Flisher, A.J., R.A. Kramer, C.W. Hoven, R.A. King, H.R. Bird, M. Davies, M.S. Gould, S. Greenwald, B.B. Lahey, D.A., Regier, M. Schwab-Stone and D. Shaffer. 2000. "Risk Behavior in a Community Sample of Children and Adolescents." Journal of the American Academy of Child and Adolescent Psychiatry 39:881-887.

Gamella, J.F. 1997. "Heroína en España (1977-1996). Balance de una crisis de drogas." Claves de Razón Práctica 72:20-30.

Gamella, J.F. 2004. "Exclusión social y diferencia étnica: el caso de los gitanos." Pp. 603-647 in Tendencias en desigualdad y exclusión social, edited by Tezanos F. Madrid: Sistema.

Garcia, F. and E. Gracia. 2009. "Is always authoritative the optimum parenting style? Evidence from Spanish families." Adolescence 44:101-131.

Gibbons, J.L., R. Bradford and D.A. Stiles 1989. "Madrid adolescents express an interest in gender roles and work possibilities." The Journal of Early Adolescence 9:125-141.

Gittelsonhn, J., K. Roche, C.H. Alexander and P. Tassler. 2001. "The social context of smoking among African-American and white adolescents in Baltimore City." Ethnicity and Health 6:211-225.

Graham, P. 2004. The end of adolescence. Oxford: Oxford University Press.

Guilamo-Ramos, V., H. A. Litardo and J. Jaccard. 2005. "Prevention Programs for Reducing Adolescent Problem Behaviors: Implications of the Co-Occurrence of Problem Behaviors in Adolescence." Journal of Adolescent Health 36:82-86.

Hazard, B.P. and C.F. Lee. 1999. "Understanding youth's health-compromising behaviors in Germany." Youth and Society 30:348-366.

Hart, G. 1999. "Risk and Health: challenges and opportunity." Health, Risk and Society 1:7-10.

Hidalgo, I., Garrido, G. and M. Hernandez. 2000. "Health Status and Risk Behavior of Adolescents in the North of Madrid, Spain." Journal of Adolescent Health 27:351-360.

INE (National Statistics Institute) 2008. Estadísticas 2008. National Statistics Institute of Spain. (http:// www.ine.es/jaxi/menu.do?type $=$ pcaxisandpath $=\% 2 \mathrm{Ft} 20 \% 2 \mathrm{Fe} 245$ andfile=inebaseandL $=0)(2-12$ 2008).

Ingersoll, G.M. and D.P. Orr. 1989. "Behavioral and emotional risk in early adolescents." The Journal of Early Adolescence 9:396-408.

INJUVE (Spanish Youth Institute) 2004. Juventud en cifras, Relaciones de Pareja. Informe de la Juventud de España. Madrid: Injuve. http://www.injuve.mtas.es/injuve/contenidos.downloadatt. action?id=532167465 (15-04-08).

Instituto de la Mujer. 2008. Interrupción voluntaria del embarazo en adolescentes. (http://www.migualdad.es/mujer/mujeres/cifras/tablas/W83-84.XLS) (12-12-2008). Madrid: Instituto de la Mujer. 
Jessor, R. 1991. "Risk behaviour in adolescence: A Psychosocial framework for understanding and action." Journal of Adolescent Health 1:597-605.

Kagan, J. 1991. "Etiologies of Adolescents at risk." Journal of Adolescent Health 12:591-596.

Kandel, D. and K. Yamaguchi. 1993. "From beer to crack: developmental patterns of drugs involvement." Am J Public Health 83:851-5.

Kobayashi, E., S. Sharp and H.G. Grasmick. 2008. "Gender and deviance: a comparison of college students in Japan and United States." Deviant Behavior 29:413-439.

Lightfoot, C. 1997. The Culture of Adolescent Risk-Taking. New York: The Guilford Press.

Maggs, J.L., D.M. Almeida and N.L. Galambos. 1995. "Risky Business. The paradoxical meaning of problem behaviour for young adolescents." The Journal of Early Adolescence 15:344-362.

Marsiglia, F., S. Killis, M.A. Luengo, T. Nieri and P. Villar. 2008. "Immigrant advantage? Substance use among Latin American immigrant and native-born youth in Spain." Ethnicity and Health 13:149-170.

Martín, E. and J.F. Gamella. 2005. "Marriage practices and differentiation: the case of Spanish Gypsies (1870-2000)." The History of the Family 10:45-63.

Millstein, S.G. and B.L. Halpern-Felsher. 2001. "Perceptions of risk and vulnerability" Pp.15-49 in Adolescent risk and vulnerability. Concepts and measurement edited by Fischhoff, B., Nightingale, E. and lannotta J. Washington: National Academy Press.

N.P.D (National Plan on Drugs). 2007. Informe de la encuesta estatal sobre uso de drogas en estudiantes de enseñanzas secundarias (ESTUDES) 2006-2007. Ministerio de Sanidad y Consumo. Secretaria General de Sanidad. Delegación del Gobierno para el Plan Nacional sobre Drogas. Madrid.

Oñederra, J.A., P. Martinez and E. Ubieta 2005. El maltrato entre iguales, bullying en Euskadi. Educación Secundaria. Vitoria-Gasteiz: Gobierno Vasco.

Rhodes, T. 1997. "Risk Theory in Epidemic Times: Sex, Drugs and the Social Organisation of 'Risk Behaviour'." Sociology of Health and IIIness 19:208-227.

Rodríguez, E., J. C. Ballesteros, I. Megías and M.A. Rodríguez. 2008. La lectura juvenil de los riesgos de las drogas: del estereotipo a la complejidad. Madrid: Fundación de Ayuda contra la Drogadicción.

Romo, N. 2001. Mujeres y drogas de sintesis. Genero y riesgo en la cultura del baile. Donostia: Tercera Prensa-Hirugarren Prentsa S.L.

Spear, H.J. and P. A. Kulbok. 2001. "Adolescent Health behaviors and related factors: A review." Public Health Nursing 18:82-93.

Weden, M.M. and L. S. Zabin. 2005. "Gender and Ethnic Differences in the Co-Occurrence of Adolescent Risk Behaviors." Ethnicity and Health 10:213-234.

Zweig, J.M., L. D. Lindberg and K.A. Mcginley. 2001. "Adolescent Health Risk Profiles: the Co-Occurrence of Health Risks Among Females and Males." Journal of Youth and Adolescence 30:707-728. 
Zwieg, J.M., S.D. Phillips and L.D. Lindberg. 2002. "Predicting Adolescent Profiles of Risk: Looking Beyond Demographics." Journal of Adolescent Health 31:343-353.

Carmen Meneses is an anthropologist and professor of Social and Cultural Anthropology at Comillas University in Madrid, Spain. She holds a PhD in Anthropology. Her main research interests are health risk behaviors. In particular, she has carried out research on risk behaviors related to drug use and unprotected sexual relations. Her publications focus on gender differences in health risk behaviors.

ANTONIO Rúa holds an undergraduate degree and a PhD in Physical Sciences, an undergraduate degree in Statistics and a master's degree in Theoretical and Applied Meteorology. He teaches Quantitative Methods in the Business and Economic Sciences Department of Comillas University, in Madrid. His research focuses on data analysis through the application of multidimensional techniques in the following fields: socio-economic analysis, academic performance, atmospheric pollution and vulnerability and social exclusion.

NuRIA Romo is an anthropologist and professor of Anthropology of Health and Illness at the University of Granada in Spain. She holds a PhD in Anthropology. She is specialized in gender and drug use and works as a member of the Institute for Women's Studies at the same University.

EugENIA GIL is a qualified nurse and also holds an undergraduate degree in Sociology and a $\mathrm{PhD}$ in Sociology from the University of Granada. Her research focuses on gender and health. She is a member of the research group Studies on Women, which is part of the Andalusian Plan for Research, Development and Innovation. She is a professor in the Nursing Department of the University of Seville.

JORGE UROz holds a PhD in Sociology and is professor of Social Policy and of Social Work involving Minors at Comillas University in Madrid. His main lines of research focus on children. In particular, he has performed research and published articles about child abuse and minors in situations of risk.

IÑAKI MARKEZ is a social researcher. He holds a PhD in Neurosciences. He is a Psychiatric Doctor employed by Osakidetza, the Basque Health Service, in Bizkaia. An expert in public health, drug dependence and clinical management, he serves as advisor in the areas of drugs and mental health for various governmental institutions, and many of his publications address this subject. $\mathrm{He}$ is chair of OME-AEN, the Basque Mental Health and Psychiatry Association.

\section{RECEIVED: 18 March 2011}

ACCEPTED: 11 December 2011 